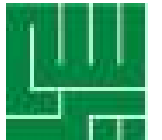

\title{
Pemeriksaan Indeks Memori, MMSE (Mini Mental State Examination) dan MoCA-Ina (Montreal Cognitive Assestment Versi Indonesia) Pada Karyawan Universitas Yarsi
}

\section{Examination of Memory Index, MMSE (Mini Mental State Examination) and MoCA-Ina (Montreal Cognitive Assestment Indonesian Version) at Yarsi University Employees}

\author{
Anna Luthfiana ${ }^{1}$, Harliansyah?" \\ 1 Department of Neurology, Faculty of Medicine, Universitas YARSI \\ ${ }^{2}$ Department of Biochemistry, Faculty of Medicine, Universitas YARSI
}

\begin{abstract}
KATA KUNCI fungsi kognitif, memori jangka pendek, Indeks memori, QRMA, MMSE, MoCA Ina

KEYWORDS cognitive function, short term memory, memori index, QRMA, MMSE, MoCA Ina
\end{abstract}

ABSTRAK Penelitian ini bertujuan untuk memeriksa indeks memori melalui alat QRMA (Quantum Resonance Magnetic Analyzer) ,pemeriksaan MMSE (Mini Mental State Examination) dan MoCA Ina (Montreal Cognitive Assestment versi Indonesia) terhadap karyawan Universitas YARSI. Hasil penelitian Indeks Memori terhadap 30 karyawan Univerisitas YARSI secara QRMA diperoleh nilai normal (Z score 0,442 - 0, 871) adalah 9 orang (30\%), menurun ringan 17 orang $(56,67 \%)$ dan menurun sedang-berat 4 orang $(13,33 \%)$. Selanjutnya hasil analisa MMSE dengan nilai normal (26 sampai 30) adalah 18 orang $(60 \%)$ dan penurunan ringan $12(40 \%)$. Adapun analisa secara MoCA Ina dengan nilai normal (26 sampai 30) menunjukkan tingkatan normal 9 orang (30\%), menurun ringan 17 orang $(56,67 \%)$ dan menurun sedang-berat 4 orang $(13,33 \%)$. Dari ketiga parameter di atas terdapat 7 orang $(23,33 \%)$ dengan semua pemeriksaan menunjukkan hasil yang normal. Terdapat 11 orang $(36,67 \%)$ dari ke tiga hasil pemeriksaan menunjukkan penurunan fungsi kognitif dan penurunan indeks memori terutama pada mereka yang berusia di atas 45 tahun. Selanjutnya 10 orang (33,33\%) dengan ke dua parameter pemeriksaan yang mengalami penurunan, serta 2 orang $(6,67 \%)$ dengan satu parameter pemeriksaan mengalami penurunan memori. Berdasarkan kepustakaan, usia berhubungan dengan penurunan fungsi memori/daya ingat. 
Tapi pada penelitian ini kami menemukan responden usia $<40$ tahun mengalami penurunan kognitif pada ke 3 parameter terutama fungsi atensi dan fungsi visuo spatial. Pemeriksaan MMSE terutama untuk menilai fungsi kognitif secara umum (fungsi atensi, bahasa,memori/daya ingat, visuo spatial dan fungsi eksekutif. Sedangkan MoCA Ina merupakan parameter untuk menilai gangguan fungsi kognitif dengan kekhususan fungsi atensi dan visuo spatial. Dari pemeriksaan Indeks memori secara QRMA, pemeriksaan MMSE dan pemeriksaan MoCA Ina, menunjukkan telah terjadi penurunan indeks memori pada karyawan yang umumnya berusia lebih dari 45 tahun, hal ini di pastikan akibat adanya sel neuron yang mengalami degeneratif akibat pengaruh stres oksidatif sehingga berpengaruh terhadap kualitas kesehatan secara keseluruhan.

ABSTRACT The aim of this study is to elaborated the level of memory especially short term memory, by using QRMA (Quantum Resonance Magnetic Analyzer), MMSE (Mini mental examination test) and MoCA-Ina (Montreal Cognitive Assestment - Indonesian version) on Yarsi University's employee. When using QRMA, from 30 sample we found 17 people $(56,67 \%)$ with mild declined, and 4 people $(13,33 \%)$ with moderate to severe declined. The $Z$ score of $Q R M A$ is 0,442-0,871; and only 9 people (30 \%) with normal Z score or normal index memory score. Due to MMSE within normal score 26-30, we found 18 people (60\%) have normal score and 12 people (40\%) have mild declined. When we analized using MoCA-Ina (normal 26-30), there were 9 people (30\%) with normal score, 17 people $(56,67 \%)$ with mild declined and 4 people $(13,33 \%)$ with moderate-severe declined. We combined the three parameter method (QRMA, MMSE, MoCA-Ina), we found only 7 people $(23,33 \%)$ showed normal result on all of the parameter. When we further analyzed, we found 11 people $(36,67 \%)$ when three parameter showed score declined from mild to severe. The cognitive declined and index memory declined especially on employee age 45 years old and above. 10 people $(33,33 \%)$ showed the declined on 2 parameter method and 2 people $(6,67 \%)$ only 1 parameter showed the declined. According to literature we knew that aging has connection with ability to memoryzed. But interestingly, we found several sample below 40 years age with mild-moderate to severe declined of this 3 parameter, may be it is due to attention function declined and visuo spatial function declined. Because we know that MMSE parameter focused especially on cognitive function (attention, language, memory, visuo spatial and executive function), but MoCA-Ina parameter focused on cognitive function especially attention and visuo spatial function. According to 3 parameter in this study (QRMA, 


\begin{abstract}
MMSE and MoCA Ina), we noticed the memory declined from mild - moderate to severe and also indez memory's declined especially employee above 45 years old. The cause of ths declined due to degenerative process of neural cell, stree oxidative process that affected neural cell; which have impact to the quality of memory and human brain, also the quality of human life.
\end{abstract}

\section{PENDAHULUAN}

Konsep kesehatan terintegrasi mencakup tiga domain yaitu: fungsi biologis, psikologis (kognitif) dan sosial. Salah satu komponen penting dalam setiap diri manusia adalah fungsi kognitif yang meliputi perhatian, persepsi, berfikir, pengetahuan dan daya ingat atau memori (Saladin, 2007). Semakin lanjut usia kita, maka sistemsistem biologis akan mengalami perubahan baik struktur dan fungsi, sehingga mempengaruhi status kesehatan (Aswin, 2003). Para ilmuwan menyatakan bahwa misteri terbesar di alam semesta adalah otak manusia. Otak manusia adalah aset manusia yang sangat berharga dengan bermacam fungsi penting seperti berfikir, fungsi fundamental seperti kesadaran (awareness), kesadaran diri (self awareness) yang dikenal sebagai fungsi kognitif. Fungsi kognitif terbagi menjadi 5 yaitu: kemampuan atensi (memperhatikan), kemampuan mengingat (memori), kemampuan mengerti pembicaraan dan berkomunikasi (bahasa), kemampuan pengenalan ruang (visuo spatial) dan kemampuan merencanakan atau melaksanakan keputusan (fungsi eksekutif) yang mana ke 5 domain tadi saling berhubungan. Dari ke 5 fungsi kognitif diatas, maka kemampuan mengingat seringkali mengalami penurunan lebih awal (Simon RP et al.,
1989; Burgess PW et al., 2003). Bruno (2004) menyebutkan bahwa, memori adalah proses mental yang meliputi pengkodean (coding), penyimpanan (storage) dan pemanggilan kembali (recall) informasi dan pengetahuan yang bepusat di otak. Menurut Richard Atkinson dan Richard Shiffrin (dalam Matlin 1998), memori tersimpan dalam 3 sistem penyimpanan yaitu memori sensorik, memori jangka pendek dan memori jangka panjang (Mayza A Lastri DN, 2015).

Fungsi kognitif seperti memori, bahasa, proses fikir, reorganisasi, reasoning ataupun pengambilan keputusan dapat mengalami penurunan akibat faktor usia, maupun karena penyakit seperti trauma kepala, stroke bahkan pada penderita kasus degeneratif seperti hipertensi dan diabetes mellitus (Mayza A et al., 2015). Penilaian gangguan memori meliputi gangguan memori anterograd/retrograd episodik; gangguan pada tahapan memori (atensi, pengkoden, penyimpanan, pemanggilan kembali dan penilaian gangguan memori semantik/episodik serta penilaian gangguan memori deklaratif/non deklaratif menggunakan indeks Katz (Simon RP et al., 1989; Waxman et al., 1995).

\footnotetext{
Correspondence:

Anna Luthfiana, Department of Neurology, Faculty of Medicine, Universitas YARSI

Email:anna.luthfiana@yarsi.ac.id
} 


\section{METODE}

\section{Pemeriksaan MMSE (Mini mental state examination)}

MMSE adalah tes yang berlangsung selama 10 menit mencakup bahasa, memori dan kalkulasi. Nilai maksimal 30 poin dengan pertanyaanpertanyaan mencakup orientasi waktu (5 poin), orientasi tempat (5 poin), registrasi (3 poin), perhatian (5 poin), mengingat kembali (3 poin), bahasa ( 2 poin), repetisi (1 poin), kemampuan mengikuti instruksi yang kompleks (3 poin). Jika seseorang memiliki nilai MMSE di bawah 24, maka kemungkinan orang tersebut menderita demensia atau paling tidak mengalami penurunan fungsi kognitif (Wibowo dkk. 2015).

\section{Pemeriksaan/penilaian MoCA-Ina (Montreal cognitive assestment versi Indonesia)}

\begin{tabular}{lccr}
\multicolumn{2}{c}{ Pemeriksaan } & MoCA & - Ina \\
bertujuan menilai & fungsi & kognitif \\
terutama daya & ingat & jangka
\end{tabular}
pendek/short term memory. Terdapat beberapa poin penilaian hasil MoCAIna diantaranya: Pemeriksaan visuo spatial eksekutif (5 poin) yaitu, peserta disuruh mengikuti urutan angka dan juga peserta diminta menggambar benda/kubus yang ada. Selanjutnya penamaan, di mana peserta diminta menyebutkan nama benda yang ada di gambar (3 poin). Adapun untuk uji memori peserta diminta mengulang beberapa kata yang dimintakan dan dilakukan 2 kali dengan jangka waktu 5 menit. Untuk uji atensi (6 poin), peserta diminta membaca daftar angka, mengetuk tangan setiap kali huruf A muncul pada huruf-huruf yang dibacakan Bahasa (3 poin): mengulangi 2 kalimat yang sudah disiapkan. Menyebutkan sebanyak mungkin kata yang dimulai dengan huruf $F$ (minimal 11 kata). Uji Abstraksi ( 1 poin) dilakukan dengan menyebutkan kemiripan benda seperti pisang-jerukbuah, kereta-sepeda. Uji Delayed recall (5 poin) dilakukan dengan cara, peserta harus mengingat kata-kata yang disebutkan tanpa mendapat petunjuk. Pada uji Orientasi (6 poin) responden diminta menyebutkan tanggal, bulan, tahun, hari, tempat dan kota (Lumempou HN dkk. 2010).

\section{Quantum Magnetic Resonance Analyzer (QMRA)}

Instrumentasi utama yang digunakan dalam penelitian ini adalah Quantum Macnetic Resonance Analyzer seri 5BA51A32C409181A dan Laptop beserta printer. Dilakukan pemeriksaan selama 60 detik untuk menilai skor Indeks memori berdasarkan $\mathrm{Z}$ score yang tersedia di alat tersebut (Fradipt25, 2014).

\section{HASIL}

Dari 30 responden (16 pria dan 14 wanita) diperoleh sebaran usia 20-45 tahun didapatkan 9 pria dan 10 wanita. Usia 46-72 tahun didapatkan 7 pria dan 4 wanita. Untuk tingkat pendidikan didapatkan kualifikasi tingkat pendidikan SMP sampai SMA atau sederajat 7 pria dan 2 wanita. Untuk tingkat sarjana (S1) dijumpai 5 pria dan 6 wanita, sedangkan tingkat pendidikan S2-S3 dijumpai 4 pria dan 6 wanita. 
Tabel 1. Pemeriksaan Indeks Memori dengan nilai normal/Z skor $0,442-0,871$

\begin{tabular}{ccccc}
\hline $\begin{array}{c}\text { Usia/Indeks } \\
\text { Memori } \\
\text { (Tahun) }\end{array}$ & $\begin{array}{c}\text { Indeks } \\
\text { Memori } \\
\text { Normal }\end{array}$ & $\begin{array}{c}\text { Indeks Memori } \\
\text { menurun ringan } \\
\text { sampai sedang }\end{array}$ & $\begin{array}{c}\text { Indeks Memori } \\
\text { menurun berat }\end{array}$ & Jumlah \\
\hline $20-45$ & $\mathbf{9}$ & $\mathbf{8}$ & $\mathbf{1}$ & $\mathbf{1 8}$ \\
$46-72$ & - & $\mathbf{9}$ & 3 & $\mathbf{1 2}$ \\
Jumlah & $\mathbf{9}$ & $\mathbf{1 7}$ & $\mathbf{4}$ & $\mathbf{3 0}$ \\
\hline
\end{tabular}

Tabel 2. Pemeriksaan Mini mental score examination(MMSE)

\begin{tabular}{cccc}
\hline $\begin{array}{c}\text { Usia/Nilai MMSE } \\
\text { Tahun) }\end{array}$ & $\begin{array}{c}\text { MMSE normal } \\
\text { Nilai MMSE 26-30 }\end{array}$ & $\begin{array}{c}\text { Gangguan memori } \\
\text { ringan-sedang } \\
\text { Nilai MMSE < 26 }\end{array}$ & Jumlah \\
\hline $20-45$ & $\mathbf{1 4}$ & $\mathbf{4}$ & $\mathbf{1 8}$ \\
$46-72$ & $\mathbf{4}$ & 8 & $\mathbf{1 2}$ \\
Jumlah & $\mathbf{1 8}$ & $\mathbf{1 2}$ & $\mathbf{3 0}$ \\
\hline
\end{tabular}

Tabel 3. Pemeriksaan Montreal Cognitive Assestment versi Indonesia (MoCA-Ina)

\begin{tabular}{|c|c|c|c|c|}
\hline $\begin{array}{c}\text { Usia } \\
\text { /Nilai } \\
\text { MoCA- } \\
\text { Ina } \\
\text { (Tahun) }\end{array}$ & $\begin{array}{c}\text { Nilai MoCa Ina } \\
\text { normal : } 26-30\end{array}$ & $\begin{array}{c}\text { Gangguan memori } \\
\text { ringan - sedang } \\
\text { (Nilai MoCa Ina 20- } \\
35)\end{array}$ & $\begin{array}{c}\text { Gangguan } \\
\text { memori berat } \\
(<20)\end{array}$ & $\underset{\mathbf{h}}{\text { Jumla }}$ \\
\hline $20-45$ & 9 & 8 & 1 & 18 \\
\hline $46-72$ & - & 9 & 3 & 12 \\
\hline Jumlah & 9 & 17 & 4 & 30 \\
\hline
\end{tabular}

Tabel 4. Perbandingan Indeks Memori dengan QRMA, MMSE dan MoCA-Ina

\begin{tabular}{|c|c|c|c|c|c|c|c|}
\hline $\begin{array}{c}\text { Usia/hasil } \\
\text { pemeriksa } \\
\text { an } \\
\text { (Tahun) }\end{array}$ & $\begin{array}{l}\text { Nor } \\
\text { mal }\end{array}$ & $\begin{array}{c}\text { Indeks } \\
\text { Memori } \\
\text { menuru } \\
\mathbf{n}\end{array}$ & $\begin{array}{c}\text { Indeks } \\
\text { memori } \\
+ \\
\text { MMSE } \\
\text { menuru } \\
\text { n }\end{array}$ & $\begin{array}{c}\text { Indeks } \\
\text { memori + } \\
\text { MoCA Ina } \\
\text { menurun }\end{array}$ & $\begin{array}{c}\text { Hasil ke } 3 \\
\text { pemeriksa } \\
\text { an } \\
\text { menurun }\end{array}$ & $\begin{array}{l}\text { MMSE } \\
\text { dan } \\
\text { MoCA } \\
\text { Ina } \\
\text { menur } \\
\text { un } \\
\end{array}$ & $\begin{array}{c}\text { Juml } \\
\text { ah }\end{array}$ \\
\hline $20-45$ & 7 & 2 & - & 5 & 3 & 1 & 18 \\
\hline $46-72$ & - & - & - & 4 & 8 & - & 12 \\
\hline Jumlah & 7 & 2 & - & 9 & 11 & 1 & 30 \\
\hline
\end{tabular}

\section{PEMBAHASAN}

Pemeriksaan Indeks memori secara Quantum resonance magnetic analysis menunjukkan responden 30\% normal dan 56,67\% menunjukkan penurunan ringan-sedang serta $13,33 \%$ menunjukkan penurunan indeks memori berat. Tabel 1 menunjukkan adanya penurunan terutama pada usia $>45$ tahun. Seperti kita ketahui bahwa penurunan fungsi kognitif terutama fungsi daya ingat jangka pendek/short term memory umumnya terjadi pada usia $>40$ tahun. Pertambahan usia menyebabkan penurunan fungsi sel 
neuron. Berdasarkan teori fisika klasik/Newtonian kita hanya bisa menganalisa hingga gangguan pada makroskopik sel neuron namun dengan perkembangan teori Fisika modern terutama teori Kuantum/Quantum mechanic, bisa dijelaskan gangguan sampai tingkat atomik bahkan sub atomic, sehingga berkembanglah alatalat kesehatan yang memakai teori Kuantum seperti QRMA (McGraig CD et al., 2009).

Selain itu pada usia di bawah 45 tahun dapat dijumpai penurunan fungsi memori mulai dari ringan-sedang sampai berat (tabel 1). Beberapa teori menjelaskan bahwa fenomena gangguan sel neuron ini, kemungkinan akibat faktor epigenetik, faktor lingkungan yang mempengaruhi hasil pemeriksaan, disamping juga pemakaian teori Kuantum yang tepat pada alat QRMA ini. Pemeriksaan Mini mental state examination (MMSE), yang umumnya dipakai secara luas untuk menentukan adanya gangguan kognitif sehingga tidak dikhususkan pada gangguan memori/daya ingat saja.

Hasil pemeriksaan ini didapatkan $40 \%$ dengan nilai MMSE yang menurun yang ternyata pada usia $>45$ tahun. Selanjutnya pemeriksaan MoCA Ina yang juga umum dipakai untuk menentukan adanya gangguan kognitif, walau pada pemeriksaan ini difokuskan untuk menilai atensi dari responden. Tabel 3 kita menjumpai 26,67\% dengan penurunan skor MoCA Ina (skor 20-25) pada usia 20-45 tahun yang kita anggap sebagai usia produktif. Terdapat 4 dari 30 responden $(13,33 \%)$ dengan penurunan skor MoCA Ina yang dianggap sebagai gangguan memori berat, dengan usia sampel terutama >50 tahun (Wibowo dkk. 2015; Lumempou HN, 2010).
Pada tabel 4 peneliti mencoba membandingkan antara ke 3 metode pemeriksaan yang dilakukan di atas dengan hasil sebanyak 23,33\% dengan skor indeks memori, skor MMSE dan skr MoCA Ina yang menunjukkan hasil normal, 36,67\% dengan hasil yang menurun dengan gradasi ringan-sedang sampai berat. Terdapat 6,67\% yang menunjukkan hasil MMSE yang menurun pada usia $<45$ tahun. Apakah ini menunjukkan gangguan memori atau gangguan kognitif lain seperti gangguan emosi dan gangguan atensi tentu memerlukan kajian lebih lanjut.

Selanjutnya hanya dijumpai sebanyak $3,33 \%$ dengan hasil indeks memori normal dan hasil MMSE serta MoCA Ina yang mengalami penurunan.

\section{SIMPULAN DAN SARAN}

\section{Saran}

Pemeriksaan Indeks memori dengan menggunakan QRMA dapat dianggap mewakili pemeriksaan awal gangguan kognitif terutama gangguan daya ingat/memori jangka pendek. Tentu saja hal ini memerlukan kajian lebih jauh. Penapisan awal dengan QRMA dapat dilakukan mengingat pemeriksaan cara ini sederhana, mudah, praktis serta membutuhkan waktu singkat (rapid).

\section{Saran}

Perlu dipertimbangkan untuk mengkonfirmasi pemeriksaan QRMA dengan pemeriksaan Brain imaging seperti fMRI atau paling tidak dengan pemeriksaan Quantitatif EEG untuk menilai gangguan fungsi kognitif berdasarkan gambaran gelombang otak/brain wave. 


\section{KEPUSTAKAAN}

Arndt M, Juffmann T, Vedral V 2009. Quantum physics meets biology. In National institutes of health web site. Bethesda, Maryland: National Institutes of health Official Web Site, US Department of Health and Human Services.

Bordonaro, M, Ogryzko V 2013. Quantum biology at the cellular level-elements of theresearch program. Scranton, USA: The Commonwealth Medical College.

Burgess PW 2003. Assestment of executive function. In Halligan PW, Marshall JC (editor): Handbook of clinical neuropsychology. New York: Oxford University Press:302-319.

Crossman AD, Neary D 2015. Cerebral hemisphere and cerebral cortex, in Neuroanatomy, An illustrated colour text. Edinburgh, England: Churchill Livingstone: 101-107.

Fradipt25 2014. Teknologi baru alat cek kesehatan Quantum resonance magnetic analyzer. www.kompasiana.com.

Grant GG 2011. Measuring stress reduction with QRMA. Hhtp://www.pekoedc.net.

Grant GG 2016. Evaluating thermotherapy using the amethyst bio belt and the infra red negative ion amethyst bio mat in 12 subjects to reduce fat, pain and stressover 3 months-case report. In Journal of Anesthesiology and critical care medicine (AACM). Canada: Enliven Academy of Wellness.

Helmenstine AM 2015. Question: How many atoms are there in a human cell ?. https://www.thought.com.

Husein N, Lumempouw S, Ramli Y 2010. Herqutanto. Uji validitas dan realibilitas Montreal cognitive assestment versi Indonesia (MoCA-Ina) untuk skrining gangguan fungsi kognitif. Dalam Neurona, Majalah Kedokteran Neuro Sains. Jakarta: Balai Penerbit FKUI: 27(4).

Kurlowics L 2012. The mini mental state examination (MMSE) at Mount Sinai Hospital. In Holsboer F.Schatzber A MD (Editor): Journal of Psychiatric Research (3). Elsevier: 189-198.

Longstaff A 2000. Section Q, Learning and memory, Q1: Types of learning. In Hames BD (editor): Neuroscience: Bios Scientific publisher, second edition, 2000: 374-379.

Mayza A, Lastri DN 2017. Neurobehaviour dasar dan pemeriksaannya dalam Buku ajar neurologi jilid 1. Penerbit kedokteran Indonesia. hal:149-180.

McCraig CD, Song B, Rajnicek AM 2009. Electrical dimensions in cell science. In Journal of Cell Science ISSN 1477-9173: 4267-4276.

Ramliyana 2015. Catatan anak desa: Sistem kelistrikan dalam tubuh manusia. fisika.blogspot.com.

Reed SK 2011. Edisi ke 7. Kognisi, terapi dan aplikasi. Dalam Tusyani A (penerjemah). Jakarta. Penerbit: Salemba Humanika; 2011. Terjemahan dari Cognition: theory and application.

Simon RP, Aminoff MJ, Greenberg DA 1989. Disorder of cognitive function: Approach to diagnosis \& acute confusional states in 1989 Clinical Neurology, Appleton \& Lange, Connecticut, USA, 1989: 1-9.

Waxman SG, de Groot J 1995. Higher cortical function in Correlative Neuroanatomi, twenty second edition. Appleton \& Lange, Connecticut, USA, 1995: 267-278.

Wibowo MM, Karema W, Maja J 2015. Gambaran fungsi kognitif dengan InaMoCA dan MMSE pada penderita post Stroke di poliklinik saraf RSUP Kandou-Manado November-Desember 2014. Jurnal e-Clinic (eCI), Volume 3, Nomer 3, September-Desember, 2015. 